\title{
Esomeprazole Magnesium
}

National Cancer Institute

\section{Source}

National Cancer Institute. Esomeprazole Magnesium. NCI Thesaurus. Code C29032.

The magnesium salt of esomeprazole, the S-isomer of omeprazole, with gastric proton pump inhibitor activity. In the acidic compartment of parietal cells, esomeprazole is protonated and converted into the active achiral sulphenamide; the active sulphenamide forms one or more covalent disulfide bonds with the proton pump hydrogen-potassium adenosine triphosphatase $(\mathrm{H}+/ \mathrm{K}+$ AT Pase), thereby inhibiting its activity and the parietal cell secretion of $\mathrm{H}+$ ions into the gastric lumen, the final step in gastric acid production. $\mathrm{H}+/ \mathrm{K}+$ ATPase is an integ ral membrane protein of the gastric parietal cell. 